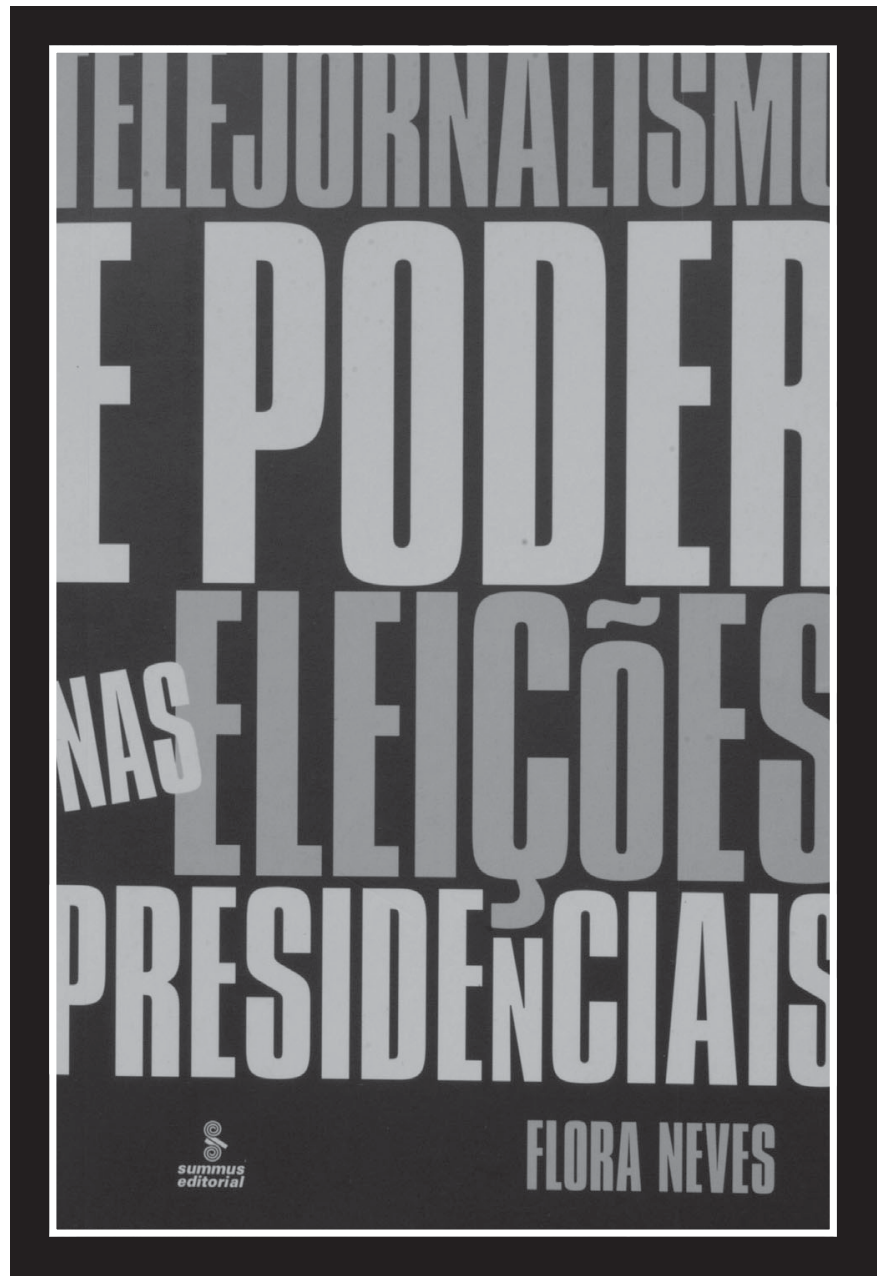

Telejornalismo e poder nas eleições presidenciais, de Flora Neves. São Paulo, Editora Summus, 2008, 231 páginas. 


\section{A prova da manipulação}

Laurindo Lalo Leal Filho*

Uma coisa é achar que a televisão manipula informações. Outra é provar. Há um sentimento difuso em parte da sociedade de que a TV não conta a verdade. Principalmente quando se trata de política e, ainda mais, às vésperas de eleições. Alguns jornais impressos chegam até a apontar distorções pontuais de um ou outro noticiário. Mas nunca dão conta de todo o processo que começa muito antes dos pleitos e só se conclui ao longo das apurações.

Para isso é necessário um trabalho em primeiro lugar independente de interesses políticos que - quase sempre - se confundem com os dos veículos de comunicação. Com a propriedade cruzada dessas empresas, admitida ainda que irregularmente no Brasil, resta pouco espaço na grande mídia para análises mais isentas. Um jornal impresso do mesmo grupo de uma emissora de TV jamais fará uma análise critica de um telejornal por ela produzido. E mesmo veículos de grupos diferentes são tímidos nas análises dos seus concorrentes. Isso porque, ao final, a maioria faz parte do mesmo grupo sócioeconômico e aposta suas fichas nos mesmos candidatos. Uns de forma explícita, outros subliminarmente.

Além da necessária independência, é preciso também vontade e disposição. Não é fácil pesquisar TV em qualquer parte do mundo. No Brasil, isso ainda fica mais difícil. O acompanhamento do veículo é, em si, trabalhoso. Gravar longas séries de programas, decupá-los, analisá-los e intepretá-los, requer muito esforço. É diferente de uma análise da mídia impressa, na qual o acesso ao material empírico é bem mais simples. E, no

\footnotetext{
* Laurindo Lalo Leal Filho é pós-doutor pela University of London (Inglaterra) e livre docente pela Universidade de São Paulo. É professor do Programa de Pós-Graduação em Ciências da Comunicação da ECA/USP e do Programa de Pós-Graduação da Faculdade de Comunicação Cásper Líbero. Autor dos livros: Atrás das câmeras: relações entre estado, cultura e televisão; $A$ melhor TV do mundo: o modelo britânico de televisão; $A T V$ sob controle: a resposta da sociedade ao poder da televisão; e Vozes de Londres: memórias brasileiras da BBC.
} 
caso brasileiro, as emissoras dificultam ao máximo o trabalho do pesquisador, restringindo o acesso aos seus arquivos.

O livro de Flora Neves, Telejornalismo e poder nas eleições presidenciais, é resultado de uma luta contra todos estes desafios. Ela os supera e ao final revela com dados incontestáveis como o principal telejornal do país manipulou a cobertura das eleições presidenciais de 2002 e 2006. Para tanto, a autora utilizou os mais avançados instrumentos metodológicos da área da comunicação na análise das edições do Jornal Nacional veiculadas naqueles períodos.

Mas o livro vai além. Os dados obtidos pela pesquisa e as suas interpretações não são apresentados ao leitor de forma isolada. A autora os circunscreve com competência publicando entrevistas inéditas que dão vida aos números. Falam personagens centrais dessa já longa e promíscua convivência entre o poder político e a principal rede de televisão do país. Estão lá depoimentos de gente que viveu a história, como o do senador Roberto Saturnino Braga que, nos anos 60, ainda como um jovem deputado, presidiu a Comissão Parlamentar de Inquérito que investigou e condenou o acordo Globo-Time Life. De Francisco Vianey Pinheiro, o Pinheirinho, responsável pela edição de política na sucursal da Globo em São Paulo e testemunha da edição fraudulenta do debate Lula-Collor em 1989. Ou do repórter Rodrigo Vianna demitido por não compactuar com as distorções impostas pela empresa à cobertura eleitoral de 2006 . E muitos outros. São testemunhos para ficar na história.

É preciso destacar também que, com este trabalho, a autora incluise no ainda reduzido grupo de pesquisadores dispostos a enfrentar esse objeto sedutor e escorradio chamado televisão. Seu poder real na sociedade brasileira ainda não é correspondido pelo número e pela qualidade das pesquisas sobre ela desenvolvidas. Flora Neves contribui para reduzir um pouco essa distância. 